\title{
Association of vitamin D deficiency, secondary hyperparathyroidism, and heterotopic ossification in spinal cord injury
}

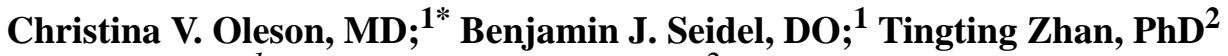 \\ Departments of ${ }^{1}$ Rehabilitation Medicine and ${ }^{2}$ Biostatistics, Jefferson Medical College of Thomas Jefferson University, \\ Philadelphia, PA
}

\begin{abstract}
Our objective was to explore the relationship between low vitamin $\mathrm{D}$, secondary hyperparathyroidism, and heterotopic ossification (HO) in patients with spinal cord injury (SCI). Ninety-six subjects with acute or chronic motor complete SCI participated. Levels of serum vitamin D25(OH), calcium, and intact parathyroid hormone (PTH) were collected, and information regarding nutritional patterns and fracture history was obtained from subjects. Evidence of current or previous $\mathrm{HO}$ was ascertained through chart review. Of the 96 subjects, 12 were found to have developed $\mathrm{HO}, 11$ with serum vitamin $\mathrm{D} 25(\mathrm{OH})$ between 5 and $17 \mathrm{ng} / \mathrm{mL}$. Nine subjects exhibited secondary hyperparathyroidism in the range of 72 to $169 \mathrm{pg} / \mathrm{mL}$. Only one subject demonstrated $\mathrm{HO}$ in the absence of low vitamin D. However, many subjects with low vitamin D (5-31 ng/mL) did not have hyperparathyroidism or HO. Statistical testing demonstrated a correlation between hyperparathyroidism and $\mathrm{HO}(p<$ 0.001 ) as well as hyperparathyroidism and vitamin D deficiency ( $<20 \mathrm{ng} / \mathrm{mL}$ ). Direct correlation between $\mathrm{HO}$ and low vitamin D was not observed, but hyperparathyroidism may increase this risk. We believe that those patients who demonstrate low vitamin D and elevated PTH should be screened for HO in addition to beginning vitamin supplementation. Initiating early treatment of low vitamin D to restore therapeutic levels may prevent development of $\mathrm{HO}$.
\end{abstract}

Key words: bone, bone morphogenic protein, bone progenitor cells, deficiency, heterotopic ossification, hyperparathyroidism, parathyroid hormone, prevention, spinal cord injury, vitamin D.

\section{INTRODUCTION}

The classical definition of heterotopic ossification (HO), set forth by Hsu and Keenan [1], focuses on the formation of lamellar bone in periarticular, nonossified soft tissues [1-2]. However, HO in its mature form reveals not only the presence of mature lamellar bone but also cancellous bone, vessels, and bone marrow with evidence of hematopoiesis [3-4]. New bone forms within the muscle planes, rather than within the muscle itself, and exists adjacent to the skeleton but exclusive of the periosteum [2].

$\mathrm{HO}$ is characterized by muscle pain, decreased range of motion (ROM), and inflammation in the affected

\footnotetext{
Abbreviations: ALK-P = alkaline phosphatase, $\mathrm{BMD}=$ bone mineral density, $\mathrm{BMP}=$ bone morphogenic protein, $\mathrm{CI}=$ confidence interval, EndMT = endothelial-mesenchymal transition, FOP = fibrodysplasia ossificans progressive, $\mathrm{HO}=$ heterotopic ossification, $\mathrm{PTH}=$ parathyroid hormone, $\mathrm{ROM}=$ range of motion, $\mathrm{SCI}=$ spinal cord injury, $\mathrm{T}=$ thoracic.

*Address all correspondence to Christina V. Oleson, MD; Jefferson Medical College of Thomas Jefferson University, Department of Rehabilitation Medicine, 132 South 10th St, Regional SCI Center of the Delaware Valley, TJUH, 375 Main Building, Philadelphia, PA 19107; 215-955-6579; fax: 215-955-5152. Email: christinavoleson@msn.com http://dx.doi.org/10.1682/JRRD.2012.11.0206
} 
region and is associated with recent trauma and soft tissue injury [1]. The reported incidence ranges from 10 to 53 percent depending on the study [5-6]. Some experts have found that, in terms of patients with traumatic spinal cord injury (SCI), HO is seen more often among those with prolonged immobility, spasticity, deep vein thromboses, or pressure ulcers [7]. Because immobility from prolonged hospitalization in an intensive care unit, ventilator dependence, and critical illness can all place a patient at risk for any of these conditions, a direct influence of pressure ulcers, spasticity, or venous thromboembolism on development of HO has been challenged [8]. Subbarao and Garrison noted that pressure ulcers and increased spasticity may be associated with $\mathrm{HO}$ yet are not considered to be causative factors [9]. However, completeness of SCI, the traumatic nature of neurological injury, and direct muscle trauma do appear to be stronger influencing factors in HO development $[1,7]$.

Although inflammation, completeness of injury, and immobility following injury may predispose the patient to heterotopic bone formation, the full scope of the condition is not observed until 1 to 4 mo after initial injury $[3,8]$. The onset of posttraumatic $\mathrm{HO}$ in the setting of acute SCI is one of several adverse sequelae seen in the subsequent months following the initial injury. Unlike other secondary adverse complications of traumatic SCI, such as pressure ulcers, venous thromboembolism, spasticity, and autonomic dysreflexia, HO has few measures of effective intervention. Treatment rarely results in complete resolution of the disorder.

In part, the challenge of prevention is related to the imprecise etiology of the condition and the various types of heterotopic bone. Subbarao and Garrison have proposed four different types of soft tissue ossification: (1) ossification due to neurologic disorders such as SCI and brain injury, (2) traumatic myositis ossificans due to blunt injury or direct contusion to the area, (3) idiopathic HO due to burns or other medical causes, and (4) congenital fibrodysplasia ossificans progressive (FOP) [9]. Whether the same or different mechanisms of formation exist among the different forms of $\mathrm{HO}$ is unknown.

Our group has recently completed an observational study of vitamin D levels in 42 subjects with acute SCI, defined as 2 to 6 mo postinjury, and 54 subjects with chronic SCI, defined as $>1$ yr postinjury [10]. A high percentage of subjects with deficient levels of vitamin D exhibited HO in bones below the neurological level of injury. Some had severe deficiency $(<13 \mathrm{ng} / \mathrm{mL})$ of vita- min D with the presence of secondary hyperparathyroidism. This group of subjects serves as the sample of study in our report. A number of our subjects with chronic SCI reported having a large bone growth on their hip or knee several months after SCI but never sought evaluation, attributing it to inactivity or discontinuing their therapy. Many did not learn its diagnosis by the name of $\mathrm{HO}$ until their annual SCI visit.

The purpose of our investigation was to examine any possible relationship between vitamin D deficiency, secondary hyperparathyroidism, and HO formation. Our specific aims were-

1. To determine whether $\mathrm{HO}$ is more common in persons with hyperparathyroidism and vitamin D deficiency.

2. To determine what minimum serum value of vitamin $D$ is necessary to reduce risk of $\mathrm{HO}$.

\section{METHODS}

Our study was a subproject of a case series examining subjects with acute (2-6 mo postinjury) and chronic (>1 yr postinjury) SCI for possible vitamin D deficiency. Table 1 shows inclusion and exclusion criteria [11]. All subjects were cervical level 3 to thoracic $(\mathrm{T})$ level 10, American Spinal Injury Association Impairment Scale grades $\mathrm{A}$ or $\mathrm{B}$, and between ages 19 and 55. The age range was derived from another study examining vitamin D levels with focus on the young and middle-aged population. Injuries caudal to T10 were eliminated to prevent possible inclusion of subjects with conus medullaris or cauda equina injuries. Both sexes and all racial groups were invited to participate.

Each subject completed a questionnaire that requested information about the following: any premorbid diagnosis of osteoporosis; history of other fractures unrelated to the original trauma; history of renal or liver failure or other liver disease (cirrhosis, hepatitis); medication use, including any seizure medications known to cause osteoporosis or to impair vitamin D absorption; family history of osteoporosis; and family or personal history of lactose intolerance. Charts were also screened for documentation of these conditions. Subjects who consumed more than $400 \mathrm{IU} / \mathrm{d}$ of vitamin D as well as those who were prescribed bisphosphonates were not eligible. These criteria were applied to both subjects with acute and chronic SCI.

Values of serum vitamin D25(OH) and intact parathyroid hormone (PTH) were collected in each subject. 
Table 1.

Criteria for participation (adapted from Oleson et al. [10]).

\begin{tabular}{|c|c|c|}
\hline Criteria & Inclusion & Exclusion \\
\hline Age (yr) & 19-55. & Outside age range. \\
\hline AIS & $\mathrm{C}^{*}$-T10 (grade A or B). & $\begin{array}{l}\text { Motor incomplete SCI (grade C or D) or neurologic level } \\
\text { below T10. }\end{array}$ \\
\hline Vitamin D & $\begin{array}{l}\text { Use of multivitamin with } 400 \text { IU cholecalciferol } \\
\text { permissible (was given to all acute participants not } \\
\text { eating well). }\end{array}$ & $\begin{array}{l}\text { Use of high-potency vitamin D supplements on regular } \\
\text { basis prior to initial assessment. Use of various medications } \\
\text { that deplete vitamin D stores, or total intake from daily sup- } \\
\text { plements exceeds } 400 \text { IU vitamin D. }\end{array}$ \\
\hline Medical History & - & $\begin{array}{l}\text { Previous diagnoses of childhood rickets or history of other } \\
\text { adult metabolic bone disorder, including osteoporosis. }\end{array}$ \\
\hline Communication & $\begin{array}{l}\text { Ability to understand consent process and agree to } \\
\text { participation. (Witnesses/assistants offered to those } \\
\text { unable to give signature). Must be able to provide } \\
\text { answers to questionnaire for patient history. }\end{array}$ & $\begin{array}{l}\text { Unable to understand English (consent not available in } \\
\text { multiple languages). Severe cognitive impairment limit- } \\
\text { ing ability to give informed consent. Other condition pre- } \\
\text { cluding consent process or questionnaire completion. }\end{array}$ \\
\hline
\end{tabular}

*May be on ventilator as long as still able to communicate to give informed consent.

AIS = American Spinal Injury Association Impairment Scale, $C=$ cervical, SCI = spinal cord injury, $\mathrm{T}=$ thoracic.

The form of vitamin D chosen for study was serum $\mathrm{D} 25(\mathrm{OH})$ since it is the major circulating vitamin D metabolite and best reflects the overall nutritional status of the subject, determined by solar and dietary sources [12]. As part of standard of care, subjects with low vitamin D levels, regardless of status of PTH values, were recommended for treatment. Some chose to pursue treatment at our clinic, while others chose to follow up with their primary care physician. In cases with severe hyperparathyroidism, subjects were referred to an endocrinologist for more intense treatment than could be provided at our center. For subjects with data available, results for follow-up are given.

Inpatient and/or outpatient charts of each subject were reviewed for reports of any diagnostic studies revealing the presence of $\mathrm{HO}$ or documentation of its presence in clinic notes. No additional images to screen for $\mathrm{HO}$ were performed for the purposes of this study. Subjects were also interviewed when data obtained from chart review were unclear. If during the interview a subject reported decreased ROM in a unilateral hip or knee, additional images may have been obtained as part of standard of care. Subjects were asked about known presence of heterotopic bone and whether they had been seen for this condition in other hospitals or clinics. No screening for $\mathrm{HO}$ was performed in the absence of notable clinical examination findings or apart from a subject's selfreported joint pain, stiffness, and decreased ROM.

\section{RESULTS}

Of the 96 subjects who participated in our previous study [10] on the presence of vitamin D deficiency, 12 reported HO as verified by review of the medical record, including imaging studies either at the institution of care or at an outside hospital. Of the 78 subjects with low vitamin D ( $<32 \mathrm{ng} / \mathrm{mL}$ ), 11 demonstrated HO formation. One patient with a normal vitamin D value of $52 \mathrm{ng} / \mathrm{mL}$ also had HO. Of the 12 subjects with HO, 9 exhibited marked hyperparathyroidism (PTH range: 71-169 pg/mL). The nine subjects with elevated PTH all had serum vitamin D levels that were deficient $(<20 \mathrm{ng} / \mathrm{mL})$. Among the subjects with low vitamin D, those with HO had serum vitamin D25(OH) levels of 5 to $17 \mathrm{ng} / \mathrm{mL}$, while those without HO ranged from 5 to $31 \mathrm{ng} / \mathrm{mL}$. There were 27 subjects with low serum D25(OH) levels between 20 and $31 \mathrm{ng} / \mathrm{mL}$, but no subjects in this range had $\mathrm{HO}$.

In all subjects with $\mathrm{HO}$, the location of bone formation was below the neurological level of injury. The most common location was the hip, followed by the knee. In two subjects, multiple joints were affected. Each subject with $\mathrm{HO}$ indicated that onset of clinical symptoms occurred after being discharged from acute inpatient rehabilitation, a duration that ranged from 30 to $65 \mathrm{~d}$. Chart review indicated that the onset of HO occurred between 6 and 12 mo postinjury for five patients and over the first $3 \mathrm{yr}$ for the others, with the exact date of onset unknown. The twelfth patient, a $48 \mathrm{yr}$ old male with hip 
$\mathrm{HO}$, had normal levels of vitamin $\mathrm{D}$ at postinjury years 1 and 2 (46 and $52 \mathrm{ng} / \mathrm{mL}$, respectively), with normal PTH and calcium levels at the time of interview. His onset appeared 2 yr postinjury. Two months after $\mathrm{HO}$ was found, the subject experienced a series of hospitalizations for weakness and fever and was diagnosed with a paraneoplastic syndrome. This was the only subject of the 96 in the study who demonstrated $\mathrm{HO}$ in the absence of low vitamin $\mathrm{D}(<32 \mathrm{ng} / \mathrm{mL})$.

Two subjects among the 78 with low vitamin D (5 and $10 \mathrm{ng} / \mathrm{mL}$, respectively) but with presence of $\mathrm{HO}$ failed to reach the level of laboratory-defined hyperparathyroidism of $>65 \mathrm{ng} / \mathrm{mL}$. Their PTH values were 40 and 56 , respectively. If left untreated for low vitamin D for additional time, those two subjects may well have demonstrated secondary hyperparathyroidism. Both were in the second year of their SCI. Of the 18 subjects with normal vitamin D levels ( $\geq 32 \mathrm{ng} / \mathrm{mL}$ ), all had therapeutic PTH values and only 1 subject had HO.

Table 2 summarizes the differences found in PTH levels and $\mathrm{HO}$ incidence among those with and without low vitamin D (serum D25(OH) levels of $<32 \mathrm{ng} / \mathrm{mL}$ ). Results indicate that presence of $\mathrm{HO}$ was correlated with elevated PTH. Vitamin D served as the stratification variable using a threshold of $32 \mathrm{ng} / \mathrm{mL}$, since this represents the lower limit of the normal range (32-100 ng/mL). The calculation was performed using a one-sided CochranMantel-Haenszel test, with odds ratio of infinity (95\% confidence interval [CI]: 43.260-infinity, $p<0.001$ ). However, presence of HO did not correlate specifically with a vitamin $\mathrm{D}$ level below $32 \mathrm{ng} / \mathrm{mL}$ by a two-sided Cochran-Mantel-Haenszel test, with odds ratio 1.953 (95\% CI: 0.032-39.608, $p=0.51$ ). Although we did observe an inverse relationship between vitamin D levels and PTH values, the correlation was not significant using $32 \mathrm{ng} / \mathrm{mL}$ as the division between abnormal and normal vitamin $\mathrm{D}$ values $(p=0.20)$.

Table 3 illustrates our findings for levels of vitamin D below $20 \mathrm{ng} / \mathrm{mL}$. Similarly, the presence of HO was correlated with elevated PTH using the lower threshold of serum vitamin D25(OH) of $20 \mathrm{ng} / \mathrm{mL}$ as the stratification variable. This relationship was determined by a one-sided Cochran-Mantel-Haenszel test, with estimated odds ratio of infinity (95\% CI: 28.193-infinity, $p<0.001)$. Presence of HO did not directly correlate with a vitamin D level below $20 \mathrm{ng} / \mathrm{mL}$ either, when calculated by a two-sided Cochran-Mantel-Haenszel test, with odds ratio 0.554 (95\% CI: 0.009-11.015, $p>0.99$ ). However, correlation
Table 2.

Cross-tabulation of parathyroid hormone (PTH) and heterotopic ossification (HO) incidence using low vitamin D threshold (serum D25(OH) level: $32 \mathrm{ng} / \mathrm{mL})$.

\begin{tabular}{|c|c|c|c|c|}
\hline \multirow{2}{*}{$\begin{array}{l}\text { PTH } \\
\text { Level }\end{array}$} & \multicolumn{2}{|c|}{$\begin{array}{l}\text { Serum D25(OH) } \\
\quad<32 \mathrm{ng} / \mathrm{mL}\end{array}$} & \multicolumn{2}{|c|}{$\begin{array}{l}\text { Serum D25(OH) } \\
\geq 32 \mathrm{ng} / \mathrm{mL}\end{array}$} \\
\hline & HO No & HO Yes & HO No & HO Yes \\
\hline Normal & 67 & 2 & 17 & 1 \\
\hline Elevated & 0 & 9 & 0 & 0 \\
\hline
\end{tabular}

Table 3.

Cross-tabulation of parathyroid hormone (PTH) and heterotopic ossification (HO) incidence using low vitamin D threshold (serum D25(OH) level: $20 \mathrm{ng} / \mathrm{mL}$ ).

\begin{tabular}{lcccccc}
\hline \multirow{2}{*}{$\begin{array}{l}\text { PTH } \\
\text { Level }\end{array}$} & \multicolumn{2}{c}{$\begin{array}{c}\text { Serum D25(OH) } \\
<\mathbf{2 0} \mathbf{~ n g / m L}\end{array}$} & & \multicolumn{2}{c}{$\begin{array}{c}\text { Serum D25(OH) } \\
\mathbf{2} \mathbf{2 0} \mathbf{~ n g / m L}\end{array}$} \\
\cline { 2 - 3 } \cline { 5 - 6 } \cline { 5 - 6 } Normal & HO No & HO Yes & & HO No & HO Yes \\
Elevated & 44 & 2 & & 40 & 1 \\
\hline \hline
\end{tabular}

does exist between vitamin $\mathrm{D}$ level $<20 \mathrm{ng} / \mathrm{mL}$ and elevated PTH. The latter finding was determined by a twosided Fisher Exact test, with estimated odds ratio of 0.000 (95\% CI: 0.000-0.476, $p=0.01$ ).

Our results suggest that the risk of developing elevated PTH appears to have an onset between serum $\mathrm{D} 25(\mathrm{OH})$ levels of 20 and $32 \mathrm{ng} / \mathrm{mL}$. While values above $20 \mathrm{ng} / \mathrm{mL}$ but below $32 \mathrm{ng} / \mathrm{mL}$ may cause mild increases in PTH, their inclusion may present a confounder when differentiating subjects with clearly therapeutic levels ( $\geq 32 \mathrm{ng} / \mathrm{mL}$ ) from those with clearly insufficient values ( $<20 \mathrm{ng} / \mathrm{mL}$ ). In the best interest of patient care, giving persons with SCI vitamin D to maintain a minimum level of $32 \mathrm{ng} / \mathrm{mL}$ may avoid onset of hyperparathyroidism that can lead to HO.

\section{FOLLOW-UP TO SUGGESTED TREATMENT FOR SUBJECTS WITH VITAMIN D DEFICIENCY}

Available $1 \mathrm{yr}$ follow-up data exists for five of nine subjects with low vitamin D, laboratory-defined hyperparathyroidism, and presence of HO. Subject 6 had a 9 mo follow-up visit, but the study concluded prior to his $1 \mathrm{yr}$ follow-up. Subjects were treated with 1,000 IU of cholecalciferol twice daily (oral vitamin D3). All subjects admitted to partial degrees of noncompliance with medication but felt that they took the pills at least 5 of $7 \mathrm{~d}$ of 
the week (72\% compliant). Although each subject was offered nonsteroidal anti-inflammatory medications for discomfort, with appropriate gastrointestinal protection, most found this medication unsuccessful at treating discomfort from the $\mathrm{HO}$, and compliance was well under 50 percent.

During the follow-up period, no subjects had additional HO formation after initiation of treatment with vitamin $\mathrm{D}$, with or without etidronate. The latter had been prescribed only for those with HO who had not reached maturity. Within 3 mo of starting vitamin D treatment, the six subjects who presented for follow up had x-ray reports indicating that maturity of HO had been reached. Their triple-phase bone scans were no longer active, and PTH values had returned to the normal range in all but one subject, whose level was $71 \mathrm{ng} / \mathrm{mL}$. Each subject had serum D25(OH) levels higher than at baseline but under the lower limit of normal (32 ng/mL).

\section{DISCUSSION}

In addressing the specific aims established at the outset of our study, we found that HO does appear to be more common in persons with hyperparathyroidism, but we were unable to support a direct correlation of $\mathrm{HO}$ with vitamin D levels. However, vitamin D25(OH) levels $<20 \mathrm{ng} / \mathrm{mL}$ were significantly (negatively) correlated with hyperparathyroidism. While it is unknown what precise value of vitamin D may place an individual at risk of developing $\mathrm{HO}$ (through its correlation with hyperparathyroidism), we advise maintaining a serum vitamin D25(OH) level $\geq 32 \mathrm{ng} / \mathrm{mL}$. Only one subject with therapeutic vitamin $\mathrm{D}$ levels demonstrated $\mathrm{HO}$, and his condition may have been attributed to a paraneoplastic syndrome.

We had 23 subjects with vitamin D levels between 20 and $31 \mathrm{ng} / \mathrm{mL}$. It could be that subjects with milder degrees of low vitamin $\mathrm{D}$ were identified early enough to prevent secondary hyperparathyroidism. An alternative explanation is that hyperparathyroidism is a secondary consequence of low vitamin $\mathrm{D}$, and in our investigation, was seen only among chronic patients. Because only a limited number of subjects had vitamin D levels between 20 and $32 \mathrm{ng} / \mathrm{mL}$, small sample size may contribute to lack of significant findings in this range.

\section{Rationale for Treatment of Low Vitamin D Levels}

Given the large number of medications already taken by those with SCI, both inpatient and outpatient, some may question the need to treat mild amounts of vitamin D deficiency. Garland et al. found that 24 percent of bone mineral density (BMD) in the distal femur of subjects with complete SCI is lost within 4 mo of SCI and 35 percent of BMD is lost within 16 mo [13]. While this early phase of SCI contains the period of greatest loss, Bauman and Spungen and Bauman et al. demonstrated continued BMD loss at a slower rate in the years following acute SCI [14-15]. The actual incidence of pathologic fractures in the population with SCI is approximately 6 percent, but this figure represents those with complete as well as incomplete SCI, where partial movement is preserved [16]. Those with complete SCI (no motor or sensory function below the injury level [17]) are estimated to have a 10 -fold greater fracture rate than subjects with incomplete SCI [16]. Given the potential contribution to continued osteoporosis following SCI, we advocate supplementation with vitamin D2 or D3 up to the reference range of 32 to $80 \mathrm{ng} / \mathrm{mL}$.

The Endocrine Society guidelines recommend an intake of at least 600 to 800 IU oral vitamin D3 for adults in the therapeutic range but advise considerably higher doses of 50,000 units of ergocalciferol (vitamin D2) weekly for $8 \mathrm{wk}$ if subjects are deficient [18]. Concerns have arisen that persons with SCI who receive vitamin D supplementation are at increased risk of kidney stones. Immobilization immediately following acute SCI does cause hypercalcemia and hypercalciuria [14], but no study has shown that supplementation with vitamin D in SCI increases this occurrence. In addition, several recent investigations of patients with a tendency for nephrolithiasis, who were treated for coexistent vitamin D deficiency, failed to show a relationship between new stone formation and vitamin D supplementation [19-21]. Eisner et al. examined 169 patients with variable levels of serum D25(OH) and found that urinary excretion of calcium was not statistically different among those with vitamin D deficiency $(<20 \mathrm{ng} / \mathrm{mL})$, those with vitamin D insufficiency (20-29 ng/mL), and those with serum D25(OH) levels $\geq 30 \mathrm{ng} / \mathrm{mL}$ [19].

Tang et al. studied 16,286 participants in the National Health and Nutrition Examination Survey [20]. Findings indicated that serum vitamin D25(OH) levels were not significantly different in stone and nonstone formers, and more specifically, that higher amounts of serum vitamin 
$\mathrm{D} 25(\mathrm{OH})$ in the 40 to $50 \mathrm{ng} / \mathrm{mL}$ range were not associated with increased stone formation. While Leaf et al. did find higher urinary excretion of calcium in 11 subjects among a small sample of 29 known stone formers, no hypercalcemia was observed and no adverse sequelae arose from the increased urinary calcium [21]. They advocated that such patients be treated for vitamin D deficiency but recommended additional monitoring of $24 \mathrm{~h}$ urinary calcium excretion following supplementation.

In looking at the calcium levels of subjects in our study, all were within the reference range of 8.5 to $10.5 \mathrm{mEq} / \mathrm{dL}$ set by our clinical laboratory [10]. It appears that the role of PTH and its interactions with proteins expressed in the posttraumatic setting, such as bone morphogenic protein (BMP), contribute more to the development of $\mathrm{HO}$ than do calcium levels alone. However, up to now, the mechanism of how $\mathrm{HO}$ forms at the cellular level has largely been speculative.

\section{Low Vitamin D Levels in African Americans}

Although normal vitamin D levels have traditionally been defined as $\geq 32 \mathrm{ng} / \mathrm{mL}$ [22-23], Wright et al. recently proposed that a lower minimum vitamin $\mathrm{D}$ value of $20 \mathrm{ng} / \mathrm{mL}$ may be adequate in African Americans [24]. Their conclusions are based on examination of large studies of African-American subjects with osteoarthritis. In these reports, PTH levels did not demonstrate upregulation unless serum vitamin D25(OH) levels were $<20 \mathrm{ng} / \mathrm{mL}$, suggesting that perhaps therapeutic values for this group have a lower limit of $20 \mathrm{ng} / \mathrm{mL}$ (range: $20-100 \mathrm{ng} / \mathrm{mL}$ ) instead of $32 \mathrm{ng} / \mathrm{mL}$ (range: $32-100 \mathrm{ng} / \mathrm{mL}$ ). Since hyperparathyroidism develops as a secondary effect to low vitamin D, it is appropriate to look at our chronic subjects in terms of our previous work [10]. However, we are unable to give clinical data to support the lack of complications in this borderline range of serum vitamin D in African Americans with chronic SCI, simply because 92.3 percent of subjects had levels less than $20 \mathrm{ng} / \mathrm{mL}$, with just one subject between 20 and $31 \mathrm{ng} / \mathrm{mL}$ and one subject with $\geq 32 \mathrm{mg} /$ $\mathrm{mL}$. Based on uncertainty of the lower limit of normal and a window of normal values extending far above that, we encourage treatment of low vitamin $\mathrm{D}$ for persons of all ethnicities up to the value of $32 \mathrm{ng} / \mathrm{mL}$, provided that an affected individual is able to tolerate oral supplementation.

Moreover, we believe that maintaining vitamin D levels in the normal range of $\geq 32 \mathrm{ng} / \mathrm{mL}$ is most desirable not only for HO prevention but also for many secondary health benefits as described in our previous work [10]. The current findings also suggest that keeping PTH within the normal range may prevent $\mathrm{HO}$ formation in the population with SCI. Because low vitamin D levels can develop within weeks of initial SCI, monitoring both vitamin D25(OH) levels and PTH levels is highly recommended in the weeks and months following initial SCI. In addition, annual surveillance of serum vitamin $\mathrm{D}$ values is also recommended since low vitamin D is even more common in the setting of chronic SCI.

\section{Proposed Mechanisms of Heterotopic Ossification Formation}

Chalmers et al. has suggested that three general conditions are needed for the formation of heterotopic bone: (1) the presence of osteogenic precursor cells, now believed to be primitive mesenchymal cells; (2) an inducing agent or stimulus that has been identified as BMP (BMP-2 vs BMP-4); and (3) a permissive environment friendly to osteogenesis [11]. The role of BMP was explored by Urist, who found that demineralized bone matrix can evoke bone formation ectopically when supplied with BMP [25]. BMP is released from healthy bone tissue in the settings of immobilization, trauma, venous stasis, and inflammation. These conditions are consistently observed in the early weeks following traumatic SCI [1]. Through the actions of BMP, mesenchymal cells in muscle are altered and transformed into osteoblasts, which then develop into mature bone cells.

Stover has affirmed that HO begins forming in the intramuscular connective tissue, first through an initial deposition of calcium phosphate, which later ossifies through deposition of hydroxyapatite crystals [26]. The hip is the most common joint affected, followed by the knee [26-27]. Elbow and shoulder joints are less commonly affected, as are smaller joints of the hand [28]. With rare exception, heterotopic bone is found below the neurological level of injury [26]. In traumatic SCI, as well as other traumatic conditions, the two primary factors that appear responsible for the etiology of bone deposition at a cellular and molecular level appear to be the presence of BMPs [2932] and the ischemic degeneration of involved muscle [33-34]. The sources of BMPs in muscle are mesenchymal cells and endothelial cells; the target cells in the muscle that BMPs act upon are mesenchymal stem cells and smooth muscle cells [35].

In a series of cell line experiments, Benayahu et al. observed that when BMP was added to mesenchymal stromal cells that were multipotent in nature (capable of differentiating into osteoblasts, fibroblasts, adipocytes, or 
other mesenchymal cells), alkaline phosphatase (ALK-P) activity increased by as much as 10 -fold [36]. These premature, mesencymal stem cells from bone marrow stroma have an inherent potential for proliferation and are considered preosteoblastic. In contrast, when BMP was added to a mature osteoblastic cell line, ALK-P activity increased by up to fivefold. We found that ALK$\mathrm{P}$ activity was increased in both forms of BMP tested, BMP-2 and BMP-3, with BMP-2 generally exhibiting more expression.

The same series of experiments was repeated with the addition of PTH to each of the mesenchymal stromal lines [36]. The premature osteoblastic cell line was noted to have three times greater ALK-P activity after PTH was added. However, PTH did not further increase the ALK-P activity in the mature osteoblastic cell line. Finally, when premature cells supplied with PTH were then challenged with BMP-2, there was a 12-fold increase in ALK-P activity. These findings suggest that hyperparathyroidism and potentially even high normal levels of PTH may the increase the risk of HO in settings of increased BMP, such as trauma and immobilization [36]. Apart from trauma, an essential anabolic action of PTH is the enhancement of osteoblastic activity [37], which may further increase the risk of $\mathrm{HO}$.

One group has recently offered a new theory that could lead to novel treatments for the condition of HO. Medici and Olsen have proposed a mechanism of endothelial-mesenchymal transition (EndMT) [38], described as a form of dedifferentiation of endothelial cells to a stem cell phenotype. This complex can subsequently form one of three types of cells: bone, cartilage, or fat. Various promoters or inhibitors that influence this primitive stem cell or a downstream intermediate may direct the ultimate fate of the cell to its destination type. Based on their analysis, Medici and Olsen propose that vascular endothelial cells are the leading candidate for the cellular origin of $\mathrm{HO}$ and its presence in FOP. In this disorder, 50 percent of bone lesions arise from an endothelial origin, but the source of the remaining lesions is unknown. Animal experiments have recently failed to show a significant contribution from vascular smooth muscle cells [39-40]. It is unclear whether a similar mechanism involving cells of endothelial origin applies in patients with SCI. The idea that human origins of $\mathrm{HO}$ may be different from those observed in previously established animal models offers new insights on treatment for a condition that has largely been resistant to pharmacologic intervention.
Other than prescribing etidronate to prevent further mineralization in established cases of HO [6,35,41-42] and using nonsteroidal anti-inflammatory agents that are contraindicated in the immediate postoperative period of spine fracture stabilization, few interventions have been attempted. Except in cases of early identification and treatment, limited gains have been achieved from these noted measures. This leaves patients with the option of pursuing surgical resection of the area of $\mathrm{HO}$ involved once it matures, raising a number of concerns in patients who may have already undergone many procedures for their original injury. Surgery carries complications of blood loss, superficial or deep wound infection, osteomyelitis, further neurologic or vascular injury, and recurrence of $\mathrm{HO}[27,43-$ 46]. Medici and Olsen report that vascular endothelial growth factor, as well as several EndMT-inducing transcription factors, may serve as potential inhibitors of $\mathrm{HO}$ formation and therefore offer another avenue of potential treatment for patients affected by HO [39].

\section{CONCLUSIONS}

HO appears to be more common in persons with elevated PTH. If vitamin D levels in patients with SCI are found to be low, supplementation to achieve a goal of serum vitamin $\mathrm{D} 25(\mathrm{OH}) \geq 32 \mathrm{ng} / \mathrm{mL}$ should be recommended. PTH levels should be checked with initial and subsequent vitamin $\mathrm{D}$ testing and closely monitored through the first year after SCI. Maintaining therapeutic serum vitamin $\mathrm{D}$ levels will reduce the likelihood of developing $\mathrm{HO}$ by creating a less permissive environment for its formation. Findings in the literature suggest that BMP-2, combined with PTH in the setting of premature osteoblasts, can increase ALK-P activity. This upregulation may contribute to the occurrence of $\mathrm{HO}$ in persons with additional risk factors, including immobility, inflammation, and hyperparathyroidism, all commonly observed in those with traumatic SCI.

\section{ACKNOWLEDGMENTS}

\section{Author Contributions:}

Study concept and design: C. V. Oleson.

Acquisition of data: C. V. Oleson.

Analysis and interpretation of data: C. V. Oleson, T. Zhan.

Drafting of manuscript: C. V. Oleson, B. J. Seidel. 
Critical revision of manuscript for important intellectual content:

C. V. Oleson, B. J. Seidel.

Statistical analysis: T. Zhan.

Administrative, technical, and material support: C. V. Oleson,

B. J. Seidel.

Study supervision: C. V. Oleson.

Financial Disclosures: The authors have declared that no competing interests exist.

Funding/Support: This material was based on work supported by intramural support from the University of Alabama at Birmingham and from Jefferson Medical College of Thomas Jefferson University.

Additional Contributions: The authors wish to thank J. Scott Richards, PhD; Amie B. McLain, MD; Samuel L. Stover, MD; and members of the research staff at the University of Alabama at Birmingham School of Medicine for their guidance and support of this project.

Institutional Review: Both the original study on vitamin D deficiency in traumatic SCI [10] and this current study (involving chart review and subject interview for information about HO) were approved by the Institutional Review Board of the University of Alabama at Birmingham School of Medicine.

Participant Follow-Up: Participants will not be informed of the publication of this study because the corresponding author no longer works at the University of Alabama at Birmingham School of Medicine. Study results will be summarized in clinic handouts that are available to all patients in their system. However, individual communication is not anticipated.

\section{REFERENCES}

1. Hsu JE, Keenan MA. Current review of heterotopic ossification. Univ PA Orthop J. 2010;20:126-30.

2. Vanden Bossche L, Vanderstraeten G. Heterotopic ossification: A review. J Rehabil Med. 2005;37(3):129-36. [PMID:16040468]

3. Shehab D, Elgazzar AH, Collier BD. Heterotopic ossification. J Nucl Med. 2002;43(3):346-53. [PMID:11884494]

4. Chantraine A, Minaire P. Para-osteo-arthropathies. A new theory and mode of treatment. Scand J Rehabil Med. 1981; 13(1):31-37. [PMID:6791273]

5. van Kuijk AA, Geurts AC, van Kuppevelt HJ. Neurogenic heterotopic ossification in spinal cord injury. Spinal Cord. 2002;40(7):313-26. [PMID:12080459]

http://dx.doi.org/10.1038/sj.sc.3101309

6. Banovac K, Williams JM, Patrick LD, Haniff YM. Prevention of heterotopic ossification after spinal cord injury with indomethacin. Spinal Cord. 2001;39(7):370-74.

[PMID:11464310]

http://dx.doi.org/10.1038/sj.sc.3101166

7. Citak M, Suero EM, Backhaus M, Aach M, Godry H, Meindl R, Schildhauer TA. Risk factors for heterotopic ossification in patients with spinal cord injury: A casecontrol study of 264 patients. Spine. 2012;37(23):1953-57.
[PMID:22614800]

http://dx.doi.org/10.1097/BRS.0b013e31825ee81b

8. Teasell RW, Mehta S, Aubut JL, Ashe MC, Sequeira K, Macaluso S, Tu L; SCIRE Research Team. A systematic review of the therapeutic interventions for heterotopic ossification after spinal cord injury. Spinal Cord. 2010;48(7): 512-21. [PMID:20048753] http://dx.doi.org/10.1038/sc.2009.175

9. Subbarao JV, Garrison SJ. Heterotopic ossification: Diagnosis and management, current concepts and controversies. J Spinal Cord Med. 1999;22(4):273-83. [PMID:10751131]

10. Oleson CV, Patel PH, Wuermser LA. Influence of season, ethnicity, and chronicity on vitamin D deficiency in traumatic spinal cord injury. J Spinal Cord Med. 2010;33(3): 202-13. [PMID:20737793]

11. Chalmers J, Gray DH, Rush J. Observations on the induction of bone in soft tissues. J Bone Joint Surg Br. 1975; 57(1):36-45. [PMID:1090627]

12. Stolzenberg-Solomon RZ. Vitamin D and pancreatic cancer. Ann Epidemiol. 2009;19(2):89-95. [PMID:18504144] http://dx.doi.org/10.1016/j.annepidem.2008.03.010

13. Garland DE, Stewart CA, Adkins RH, Hu SS, Rosen C, Liotta FJ, Weinstein DA. Osteoporosis after spinal cord injury. J Orthop Res. 1992;10(3):371-78. [PMID:1569500] http://dx.doi.org/10.1002/jor.1100100309

14. Bauman WA, Spungen AM. Metabolic changes in persons after spinal cord injury. Phys Med Rehabil Clin N Am. 2000;11(1):109-40. [PMID:10680161]

15. Bauman WA, Spungen AM, Wang J, Pierson RN Jr, Schwartz E. Continuous loss of bone during chronic immobilization: A monozygotic twin study. Osteoporos Int. 1999;10(2):123-27. [PMID:10501792] http://dx.doi.org/10.1007/s001980050206

16. Ragnarsson KT, Sell GH. Lower extremity fractures after spinal cord injury: A retrospective study. Arch Phys Med Rehabil. 1981;62(9):418-23. [PMID:7283682]

17. American Spinal Injury Association. International standards for neurological classification of spinal cord injury. Atlanta (GA): American Spinal Injury Association; 2011.

18. Holick MF, Binkley NC, Bischoff-Ferrari HA, Gordon CM, Hanley DA, Heaney RP, Murad MH, Weaver CM; Endocrine Society. Evaluation, treatment, and prevention of vitamin D deficiency: An Endocrine Society clinical practice guideline. J Clin Endocrinol Metab. 2011;96(7): 1911-30. [PMID:21646368] http://dx.doi.org/10.1210/jc.2011-0385

19. Eisner BH, Thavaseelan S, Sheth S, Haleblian G, Pareek G. Relationship between serum vitamin D and 24-hour urine calcium in patients with nephrolithiasis. Urology. 2012; 80(5):1007-10. [PMID:22698470] http://dx.doi.org/10.1016/j.urology.2012.04.041 
20. Tang J, McFann KK, Chonchol MB. Association between serum 25-hydroxyvitamin D and nephrolithiasis: The National Health and Nutrition Examination Survey III, 1988-94. Nephrol Dial Transplant. 2012;27(12):4385-89. [PMID:22778177] http://dx.doi.org/10.1093/ndt/gfs297

21. Leaf DE, Korets R, Taylor EN, Tang J, Asplin JR, Goldfarb DS, Gupta M, Curhan GC. Effect of vitamin D repletion on urinary calcium excretion among kidney stone formers. Clin J Am Soc Nephrol. 2012;7(5):829-34.

[PMID:22422535] http://dx.doi.org/10.2215/CJN.11331111

22. Heaney RP. Lessons for nutritional science from vitamin D. Am J Clin Nutr. 1999;69(5):825-26. [PMID:10232617]

23. Heaney RP, Dowell MS, Hale CA, Bendich A. Calcium absorption varies within the reference range for serum 25hydroxyvitamin D. J Am Coll Nutr. 2003;22(2):142-46. [PMID:12672710] http://dx.doi.org/10.1080/07315724.2003.10719287

24. Wright NC, Chen L, Niu J, Neogi T, Javiad K, Nevitt MA, Lewis CE, Curtis JR. Defining physiologically "normal” vitamin D in African Americans. Osteoporos Int. 2012; 23(9):2283-91. [PMID:22189572] http://dx.doi.org/10.1007/s00198-011-1877-6

25. Urist MR. Bone morphogenetic protein: the molecularization of skeletal system development. J Bone Miner Res. 1997;12(3):343-46. [PMID:9076576]

26. Stover SL. Heterotopic ossification after spinal cord injury. In: Bloch RF, Basbaum M, editors. Management of spinal cord injuries. Baltimore (MD): Williams \& Wilkins; 1986. p. 284-301.

27. Garland DE, Orwin JF. Resection of heterotopic ossification in patients with spinal cord injuries. Clin Orthop Relat Res. 1989;(242):169-76. [PMID:2495875]

28. Meythaler JM, Tuel SM, Cross LL, Mathew MM. Heterotopic ossification of the extensor tendons in the hand associated with traumatic spinal cord injury. J Am Paraplegia Soc. 1992;15(4):229-31. [PMID:1431870]

29. Yamaguchi A, Katagiri T, Ikeda T, Wozney JM, Rosen V, Wang EA, Kahn AJ, Suda T, Yoshiki S. Recombinant human bone morphogenetic protein-2 stimulates osteoblastic maturation and inhibits myogenic differentiation in vitro. J Cell Biol. 1991;113(3):681-87. [PMID:1849907] http://dx.doi.org/10.1083/jcb.113.3.681

30. Chen D, Ji X, Harris MA, Feng JQ, Karsenty G, Celeste AJ, Rosen V, Mundy GR, Harris SE. Differential roles for bone morphogenetic protein (BMP) receptor type IB and IA in differentiation and specification of mesenchymal precursor cells to osteoblast and adipocyte lineages. J Cell Biol. 1998;142(1):295-305. [PMID:9660882] http://dx.doi.org/10.1083/jcb.142.1.295
31. Wozney JM. The bone morphogenetic protein family and osteogenesis. Mol Reprod Dev. 1992;32(2):160-67.

[PMID:1637554]

http://dx.doi.org/10.1002/mrd.1080320212

32. Bosch P, Musgrave DS, Lee JY, Cummins J, Shuler T, Ghivizzani TC, Evans T, Robbins TD, Huard. Osteoprogenitor cells within skeletal muscle. J Orthop Res. 2000; 18(6):933-44. [PMID:11192254] http://dx.doi.org/10.1002/jor.1100180613

33. Gonda K, Nakaoka T, Yoshimura K, Otawara-Hamamoto Y, Harrii K. Heterotopic ossification of degenerating rat skeletal muscle induced by adenovirus-mediated transfer of bone morphogenetic protein-2 gene. J Bone Miner Res. 2000;15(6):1056-65. [PMID:10841174] http://dx.doi.org/10.1359/jbmr.2000.15.6.1056

34. Nakamura Y, Wakitani S, Nakayama J, Wakabayashi S, Horiuchi H, Takaoka K. Temporal and spatial expression profiles of BMP receptors and noggin during BMP-2induced ectopic bone formation. J Bone Miner Res. 2003; 18(10):1854-62. [PMID:14584896] http://dx.doi.org/10.1359/jbmr.2003.18.10.1854

35. Banovac K, Williams JM, Patrick LD, Levi A. Prevention of heterotopic ossification after spinal cord injury with COX-2 selective inhibitor (rofecoxib). Spinal Cord. 2004; 42(12):707-10. [PMID:15179440] http://dx.doi.org/10.1038/sj.sc.3101628

36. Benayahu D, Fried A, Wientroub S. PTH and 1,25(OH)2 vitamin $\mathrm{D}$ priming to growth factors differentially regulates the osteoblastic markers in MBA-15 clonal subpopulations. Biochem Biophys Res Commun. 1995;210(1):197-204. [PMID:7741741] http://dx.doi.org/10.1006/bbrc.1995.1646

37. Canalis E. Update in new anabolic therapies for osteoporosis. J Clin Endocrinol Metab. 2010;95(4):1496-1504. [PMID:20375217] http://dx.doi.org/10.1210/jc.2009-2677

38. Medici D, Olsen BR. The role of endothelial-mesenchymal transition in heterotopic ossification. J Bone Miner Res. 2012;27(8):1619-22. [PMID:22806925] http://dx.doi.org/10.1002/jbmr.1691

39. Medici D, Shore EM, Lounev VY, Kaplan FS, Kalluri R, Olsen BR. Conversion of vascular endothelial cells into multipotent stem-like cells. Nat Med. 2010;16(12):1400-1406. [PMID:21102460] http://dx.doi.org/10.1038/nm.2252

40. Lounev VY, Ramachandran R, Wosczyna MN, Yamamoto M, Maidment AD, Shore EM, Glaser DL, Goldhamer DJ, Kaplan FS. Identification of progenitor cells that contribute to heterotopic skeletogenesis. J Bone Joint Surg Am. 2009; 91(3):652-63. [PMID:19255227] http://dx.doi.org/10.2106/JBJS.H.01177 
41. Banovac K, Gonzalez F, Renfree KJ. Treatment of heterotopic ossification after spinal cord injury. J Spinal Cord Med. 1997;20(1):60-65. [PMID:9097258]

42. Banovac K, Gonzalez F, Wade N, Bowker JJ. Intravenous disodium etidronate therapy in spinal cord injury patients with heterotopic ossification. Paraplegia. 1993;31(10): 660-66. [PMID:8259329] http://dx.doi.org/10.1038/sc.1993.106

43. Meiners T, Abel R, Böhm V, Gerner HJ. Resection of heterotopic ossification of the hip in spinal cord injured patients. Spinal Cord. 1997;35(7):443-45.

[PMID:9232749]

http://dx.doi.org/10.1038/sj.sc.3100415

44. Freebourn TM, Barber DB, Able AC. The treatment of immature heterotopic ossification in spinal cord injury with combination surgery, radiation therapy and NSAID. Spinal Cord. 1999;37(1):50-53. [PMID:10025696]

http://dx.doi.org/10.1038/sj.sc.3100719

45. Subbarao JV, Nemchausky BA, Gratzer M. Resection of heterotopic ossification and Didronel therapy-regaining wheelchair independence in the spinal cord injured patient. J Am Paraplegia Soc. 1987;10(1):3-7. [PMID:3106569]
46. Jamil F, Subbarao JV, Banaovac K, El Masry WS, Bergman SB. Management of immature heterotopic ossification (HO) of the hip. Spinal Cord. 2002;40(8):388-95. [PMID:12124665]

http://dx.doi.org/10.1038/sj.sc.3101305

Submitted for publication November 15, 2012. Accepted in revised form May 28, 2013.

This article and any supplementary material should be cited as follows:

Oleson CV, Seidel BJ, Zhan T. Association of vitamin D deficiency, secondary hyperparathyroidism, and heterotopic ossification in spinal cord injury. J Rehabil Res Dev. 2013;50(9):1177-86.

http://dx.doi.org/10.1682/JRRD.2012.11.0206

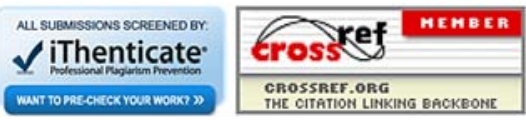

